J. Clin. Chem. Clin. Biochem.

Vol. 24, 1986, pp. 627-635

(C) 1986 Walter de Gruyter \& Co.

Berlin - New York

\title{
HDL Apolipoprotein A-I and HDL Apolipoprotein A-II Concentrations in Male Company Employees in Westphalia Aged 40 Years and Older
}

\author{
By $H$. Schriewer, F. Emke, H. Funke \\ Institut für Klinische Chemie und Laboratoriumsmedizin (Zentrallaboratorium) Medizinische Einrichtungen der \\ Westfälischen Wilhelms-Universität Münster/Westfalen
}

H. Schulte

Institut für Arterioskleroseforschung an der Universität Münster, Münster/Westfalen and

G. Assmann

Institut für Klinische Chemie und Laboratoriumsmedizin (Zentrallaboratorium) Medizinische Einrichtungen der Westfälischen Wilhelms-Universität Münster/Westfalen

(Received January 10, 1985/January 2/April 30, 1986)

Summary: The major structural components of high density lipoproteins were determined in the sera of 638 male employees aged 40 years and older. It was demonstrated that the HDL apolipoprotein A-I/HDL cholesterol ratio as well as the HDL apolipoprotein $\mathrm{A}-\mathrm{II} / \mathrm{HDL}$ cholesterol ratio are similarly correlated to a cumulative score of established risk factors for atherosclerosis. Most important, however, is the finding that the correlation of these ratios to the risk factor rating of atherosclerosis is found in subgroups with normal or elevated HDL cholesterol values. Furthermore, it is shown that the relative content of apolipoproteins AI and A-II in individual HDL is partly dependent on the plasma concentration of HDL cholesterol and triglycerides.

It is concluded that HDL composition may have an additional predictive significance for the development of atherosclerosis.

HDL-Apolipoprotein A-I- und HDL-Apolipoprotein A-II-Konzentrationen bei männlichen Betriebsangehörigen in Westfalen im Alter von 40 Jahren und darüber

Zusam̈menfassung: Im Serum von 638 männlichen Betriebsangehörigen im Alter von 40 Jahren und darüber wurden die Hauptstrukturikomp̈onenten der "high density" Lipoproteine untersucht. Es wird gezeigt, daß sowohl das HDL-Apolipoprotein A-I/HDL-Cholesterin-Verhältnis als auch das HDL-Apolipoprotein A-II/ HDL-Cholesterin-Verhältnis vergleichbar mit einem kumulativen Score von bekannten Risikofaktoren der Atherosklerose korreliert ist. Am bedeutsamsten ist die Beobachtung, daß die Korrelation zwischen diesen Quotienten und dem Risiko-Score in Untergruppen mit normalen und erhöhten HDL-Cholesterinwerten erhalten bleibt. Darüberhinaus wird gezeigt, daß der relative Anteil von Apolipoprotein A-I und Apolipoprotein A-II in den HDL teilweise von der Konzentration von HDL-Cholesterin und Triglyceriden im Plasma abhängt.

Die Ergebnisse deuten darauf hin, daß der HDL-Komposition eine zusätzliche prädiktive Bedeutung für die Entwicklung der Atherosklerose zukommt.

J. Clin. Chem. Clin. Biochem. / Vol. 24, 1986 / No. 9 


\section{Introduction}

In recent epidemiological $(1-4)$ and clinical studies $(5-6)$ the analysis of high density lipoprotein cholesterol (HDL cholesterol) has been shown to be a risk indicator for coronary heart disease. In contrast to HDL cholesterol, the possible relationship of HDL apolipoproteins to the risk of coronary heart disease has not yet been thoroughly investigated. Several clinical studies have demonstrated low levels of apolipoprotein A-I in subjects with coronary heart disease (7-9), while apolipoprotein A-II in patients with coronary heart disease has been found to be low (10, 11) or unchanged $(6,8)$. In contrast to these clinical studies there is a lack of the prospective epidemiological data needed to demonstrate the predictive potency of HDL apolipoproteins with respect to coronary heart disease. Recently, from initial results of our epidemiological study in company employees in Westphalia, it was demonstrated that HDL apolipoprotein A-I correlates with several risk factors for coronary heart disease but fails to correlate with the risk factors triacylglycerol and relative body weight (12). To date, no comparable studies on HDL apolipoprotein A-II are available. For a greater insight into the relationship between HDL apolipoproteins and the risk factors for coronary heart disease, we measured both HDL apolipoproteins A-I and A-II in 638 male company employees in addition to $\mathrm{HDL}$ cholesterol. Since the incidence of coronary heart disease in women and in men under 40 years of age is very low, our study was limited to individuals aged 40 years and above.

\section{Materials and Methods}

\section{Sample material}

Sera were obtained from male employees aged 40 years and over. All of these were participants in the "Prospective epidemiological study of company employees in Westphalia" (13). Data given here are cross sectional. The proband's mean age was $49 \pm 6$ years, the maximum age being 64 years; observed body weight expressed as Broca index ranged from $69 \%$ to $151 \%$ with a mean value of $106.6 \% \pm 12.2 \%$.

\section{Analysis of HDL components}

HDL components were analysed in the supernatant after precipitation of apolipoprotein B-containing lipoproteins with phosphotungstic acid/ $\mathrm{MgCl}_{2}$ using the Boehringer Mannheim Test Combination (test no. 1442434) (14). HDì cholesterol was analysed enzymatically using the CHOD-PAP method (Boehringer Mannheim, test combination nol 237574) (14). HDL phosphatidyl choline was determined with an enzymatic colour test using the centrifugal analyser Cobas Bio (Hoffmann La Roche) as described previously (15).

Apolipoprotein A-I was determined turbidimetrically using the Cobas Bio analyser.
The incubation mixture contained:

- $300 \mu l$ phosphate-buffered polyethyleneglycol solution (Immunochemical System Beckman)

- $20 \mu$ l diluted sample (dilution $1: 160$ with $9 \mathrm{~g} / 1 \mathrm{NaCl}$ )

- $20 \mu \mathrm{l}$ antibody solution (Behring antibody no. $103315 \mathrm{~B}$ was diluted with $1: 2.5$ with $9 \mathrm{~g} / 1: \mathrm{NaCl}$ )

$-10 \mu \mathrm{l} \mathrm{H}_{2} \mathrm{O}$

As a blank, $300 \mu l$ phosphate-buffered polyethyleneglycol solution was used, containing $20 \mu$ l diluted sample (dilution $1: 160$ with $9 \mathrm{~g} / 1 \mathrm{NaCl}$ ) and $10 \mu \mathrm{l} \mathrm{H}_{2} \mathrm{O}$. After an incubation period at $25^{\circ} \mathrm{C}$ changes in turbidity were recorded 30 times. For calibration, a standard solution of known concentration (Behring Apolipoprotein A Standard Serum Lot No. A 041206 K) was diluted $1: 30,1: 60,1: 120,1: 240$, and $1: 480$ with $9 \mathrm{~g} / 1 \mathrm{NaCl}$.

The parameter list for the Cobas Bio reads as follows:

1 unit
2 calculation factor
3 standard 1 conc
3 standard 2 conc
3 standard 3 conc
3 standard 4 conc
3 standard 5 conc
6 limit
7 temperature $\left({ }^{\circ} \mathrm{C}\right)$
8 type of analysis
9 wavelength $(\mathrm{nm})$
10 sample dilution $(\mu l)$
11 diluent volume $(\mu l)$
12 reagent volume $(\mu \mathrm{l})$
13 incubation time $(\mathrm{s})$
14 start reagent volume $(\mu \mathrm{l})$
15 time of first reading $(\mathrm{s})$
16 time interval $(\mathrm{s})$
17 number of readings
18 blanking mode
19 printout mode

$8(\mathrm{mg} / \mathrm{dl})$
1000
23.1
46.2
92.4
184.8
369.6
0
25.0
7.6
340
20
20
300
10
20
1.0
10
30
1
1

Using this turbidimetric method identical results were obtained when compared with data observed using kinetic nephelometry (16).

HDL apolipoprotein A-II was measured by turbidimetry using the Cobas Bio analyser as described in detail elsewhere (17).

\section{LDL cholesterol}

LDL cholesterol was calculated using the Friedewald method (18).

Total cholesterol, triacylglycerol, uric acid

Serum levels of cholesterol, triacylglycerol, glucóse and uric acid were determined with the SMAC II Analyser (Technicon GmbH, Bad Vilbel, FRG) as described elsewhere (13).

\section{Statistics}

For statistical calculations we used the statistical package for the social sciences (SPSS). To describe telationships to risk factors Spearman's correlation coefficients were chosen since the risk factors were not always normally distributed, as proved by the Kolmogorov-Smirnow test. The correlations of apolipoproteins to the coronary risk score were calculated by Kendalls $\tau$ because of the high number of tied ranks. Differences in the distribution between subgroups were tested by the KruskalWallis test. The level of significance was set at $0.0 \overline{5}$. 


\section{Results}

Distribution of HDL apolipoprotein A-I and A-II

Figure 1 shows the HDL apolipoprotein A-I values measured in company employees $\mathbf{4 0}$ years and older. The parameters of distribution were:

mean: $1.444 \mathrm{~g} / 1$,

S. D.: $\pm 0.222 \mathrm{~g} / \mathrm{l}$, median: $1.435 \mathrm{~g} / \mathrm{l}$, minimum $0.75 \mathrm{~g} / \mathrm{l}$, maximum $2.65 \mathrm{~g} / \mathrm{l}$, $\mathrm{n}=617$.
The corresponding values of apolipoprotein A-II are shown in figure 2 :

mean: $0.427 \mathrm{~g} / 1$,

S. D.: $\pm 0.073 \mathrm{~g} / \mathrm{l}$,

median: $0.423 \mathrm{~g} / \mathrm{l}$,

minimum: $0.248 \mathrm{~g} / \mathrm{l}$,

maximum: $0.748 \mathrm{~g} / \mathrm{l}$,

$\mathrm{n}=638$.

Correlation to cumulative risk factor rating

To test the relationship between HDL cholesterol, HDL apolipoprotein A-I/HDL cholesterol ratio,

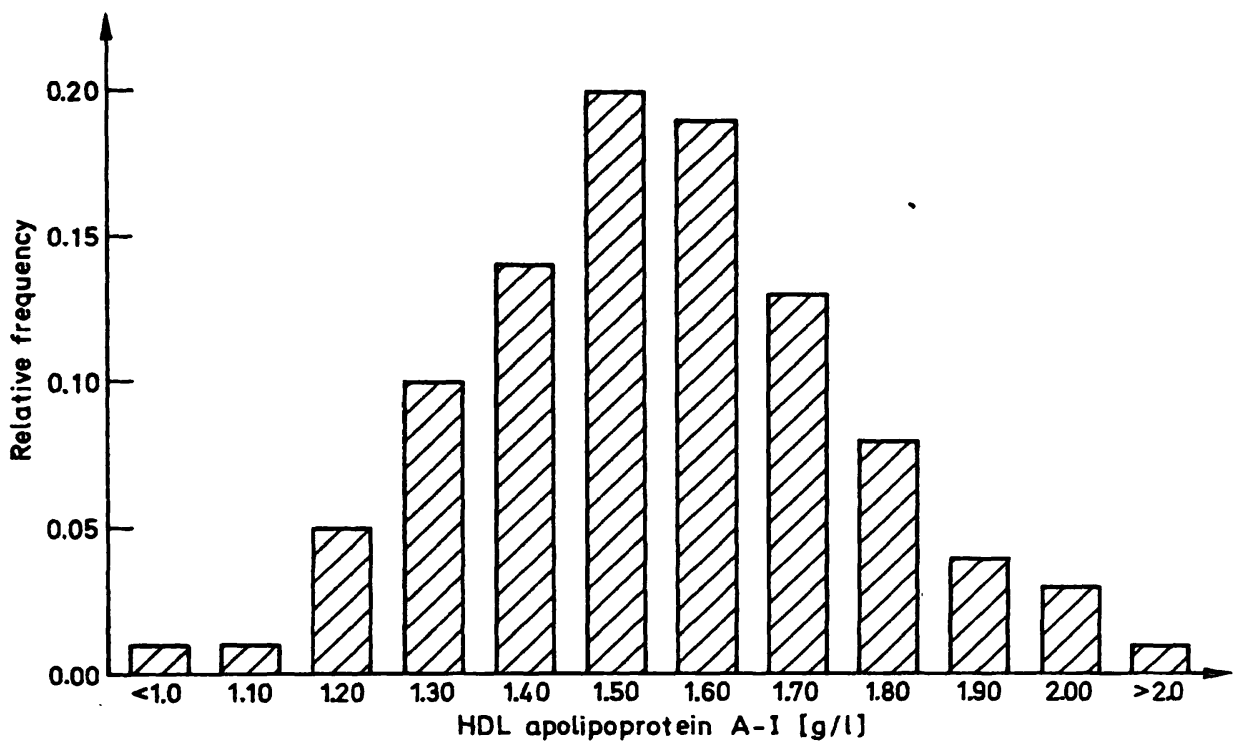

Fig. 1. HDL apolipoprotein A-I values $(\mathrm{g} / \mathrm{l})$ in 616 normal male individuals 40 years and older. Epidemiological study of company employees in Westphalia - cross sectional data. On the horizontal axis the upper bounds of the intervals are given.

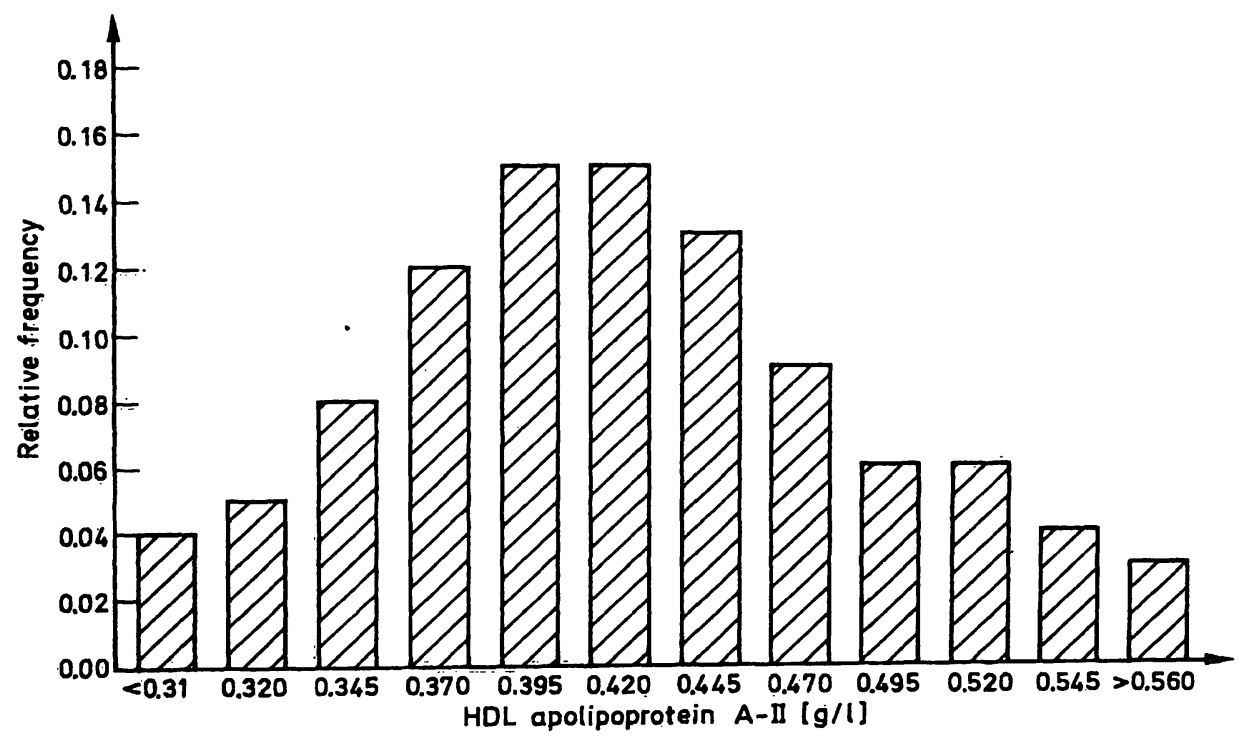

Fig. 2. HDL apolipoprotein A-II values $(\mathrm{g} / \mathrm{l})$ in 638 normal male individuals 40 years and older. Epidemiological study of company employees in Westphalia - cross sectional data. On the horizontal axis the upper bounds are given. 
HDL apolipoprotein A-II/HDL cholesterol ratio and risk factors, a cumulative risk factor rating was established for each subject. It was based on relative weight, diastolic blood pressure, cigarette smoking, cholesterol value and exercise. A score of 0,1 or 2 was allocated for each of these measurements (tab. 1) and the sum of these individual scores was taken as the cumulative rating (19). The relation between each of the three parameters and increasing risk score was significant $(p<0.001$ each). The distribution of the three parameters in the subgroups with a cumulative risk rating score of $0,1,2-6$ are demonstrated in figures 3,4 and 5 where additionally the median values are indicated. The differences in the distributions between the subgroups are significant (Kruskal-Wallis test, $\mathrm{p}<0.001$ each). The relationship between the HDL apolipoprotein A-I/HDL cholesterol ratio and the cumulative risk rating score was comparable to the relationship of HDL cholesterol and the risk iscore (tab. 2).
Tab. 1. Risk rating score sheet.

\begin{tabular}{llll}
\hline & 0 point & 1 point & 2 points \\
\hline $\begin{array}{l}\text { Relative body weight } \\
\text { (Broca Index, \%) }\end{array}$ & $<100$ & $100-120$ & $>120$ \\
$\begin{array}{l}\text { Diastolic blood pressure } \\
\text { (mm Hg) }\end{array}$ & $<90$ i & $90-110$ & $>110$ \\
$\begin{array}{l}\text { Cigarette smoking } \\
\text { (no./day) }\end{array}$ & non-smoker & $1-20$ & $>20$ \\
$\begin{array}{l}\text { Cholesterol } \\
\text { (mmol/) }\end{array}$ & $<6.72$ & $6.72-7.75$ & $>7.75$ \\
Exercise & very & slightly & inactive \\
& active & active & \\
\hline
\end{tabular}

An analysis of subgroups with low $(<0.91 \mathrm{mmol} / \mathrm{l})$, normal $(0.91-1.40 \mathrm{mmol} / \mathrm{l})$ or elevated $(>1.40$ mmol/l) HDL cholesterol values revealed that the two ratios were related to the cumulative risk factor rating in subjects with normal or elevated HDL cho-

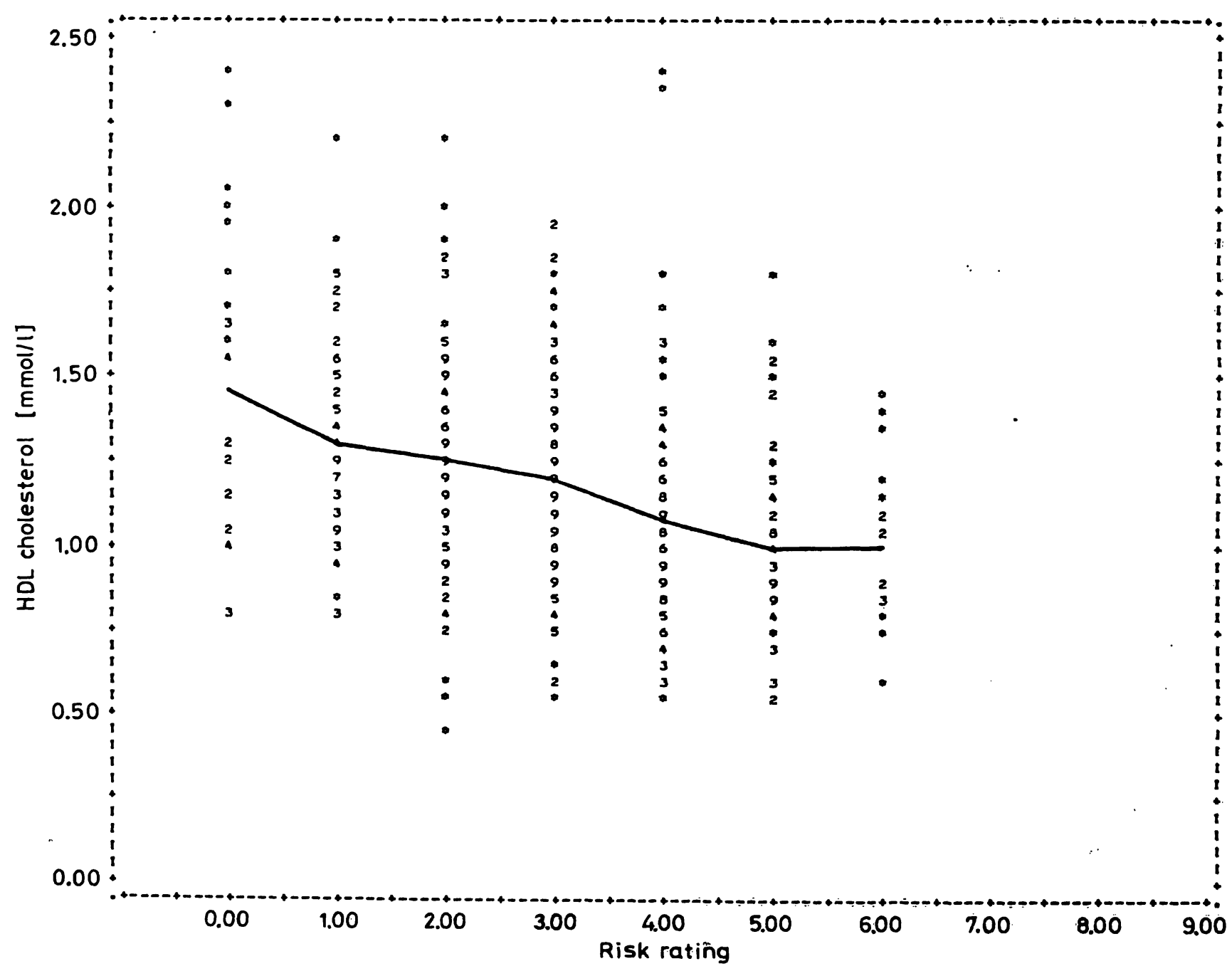

Fig. 3. HDL cholesterol in relation to cumulative risk factor rating. A ' 9 ' is printed if 9 or more men' have equal values. $r($ Kendal $)=-0.280(p<0.001)$ 
Tab. 2. Correlation coefficients (Kendalls $\tau$ ) between the coronary risk score and HDL-cholesterol, HDL apolipoprotein A-I/HDL cholesterol, HDL apolipoprotein AII/HDL cholesterol.

\begin{tabular}{|c|c|c|c|}
\hline & $\begin{array}{l}\text { HDL apo- } \\
\text { lipoprotein } \\
\text { A-I/HDL } \\
\text { cholesterol }\end{array}$ & $\begin{array}{l}\text { HDL apo- } \\
\text { lipoprotein } \\
\text { A-II/HDL } \\
\text { cholesterol }\end{array}$ & $\begin{array}{l}\text { HDL } \\
\text { cholesterol }\end{array}$ \\
\hline $\begin{array}{l}\text { HDL cholesterol } \\
<0.907 \mathrm{mmol} / 1\end{array}$ & $\begin{array}{l}0.092 \\
\mathrm{n}=112\end{array}$ & $\begin{array}{l}0.026 \\
\mathrm{n}=114\end{array}$ & $\begin{array}{l}0.070 \\
n=114\end{array}$ \\
\hline $\begin{array}{l}\text { HDL cholesterol } \\
0.907-1.424 \mathrm{mmol} / 1\end{array}$ & $\begin{array}{l}0.260^{* * *} \\
\mathrm{n}=369\end{array}$ & $\begin{array}{l}0.206 * * * \\
n=381\end{array}$ & $\begin{array}{l}-0.109^{*} \\
\mathrm{n}=381\end{array}$ \\
\hline $\begin{array}{l}\text { HDL cholesterol } \\
>1.424 \mathrm{mmol} /\end{array}$ & $\begin{array}{l}0.149 * \\
n=135\end{array}$ & $\begin{array}{l}0.206 \\
\mathrm{n}=142\end{array}$ & $\begin{array}{l}-0.097 \\
n=142\end{array}$ \\
\hline Total group & $\begin{array}{l}0.300^{* * * *} \\
\mathrm{n}=616\end{array}$ & $\begin{array}{l}0.287^{* * *} \\
\mathrm{n}=637\end{array}$ & $\begin{array}{l}-0.280^{* * * *} \\
\mathrm{n}=637\end{array}$ \\
\hline
\end{tabular}

$* \mathrm{p}<0.05$

$* * \mathrm{p}<0.01$

$* * * \mathrm{p}<0.001$ lesterol values (tab. 2). Therefore, it seems possible that in subjects with normal or elevated HDL cholesterol values, high ratios of HDL apolipoprotein A-I/HDL cholesterol and HDL apolipoprotein A-II/ HDL cholesterol reflects an increased risk of developing coronary heart disease.

HDL apolipoprotein $A-I / H D L$ apolipoprotein A-II ratio

The HDL apolipoprotein A-I/HDL apolipoprotein A-II ratio was positively correlated with HDL cholesterol $(r=0.194, p<0.001)$ (tab. 3, fig. 6). Furthermore, in individuals with low HDL cholesterol values $(<0.907 \mathrm{mmol} / \mathrm{l})$, a relatively low HDL-apolipoprotein A-I/HDL apolipoprotein A-II ratio (3.23 $\pm 0.47)$ was calculated. Individuals with high $\mathrm{HDL}$ cholesterol values (>1.41 mmol/l) showed significantly higher HDL apolipoprotein A-I/HDL apolipoprotein A-II ratios $(3.67 \pm 0.52, \mathrm{p}<0.001)$. The HDL apolipoprotein A-I/HDL apolipoprotein A-II

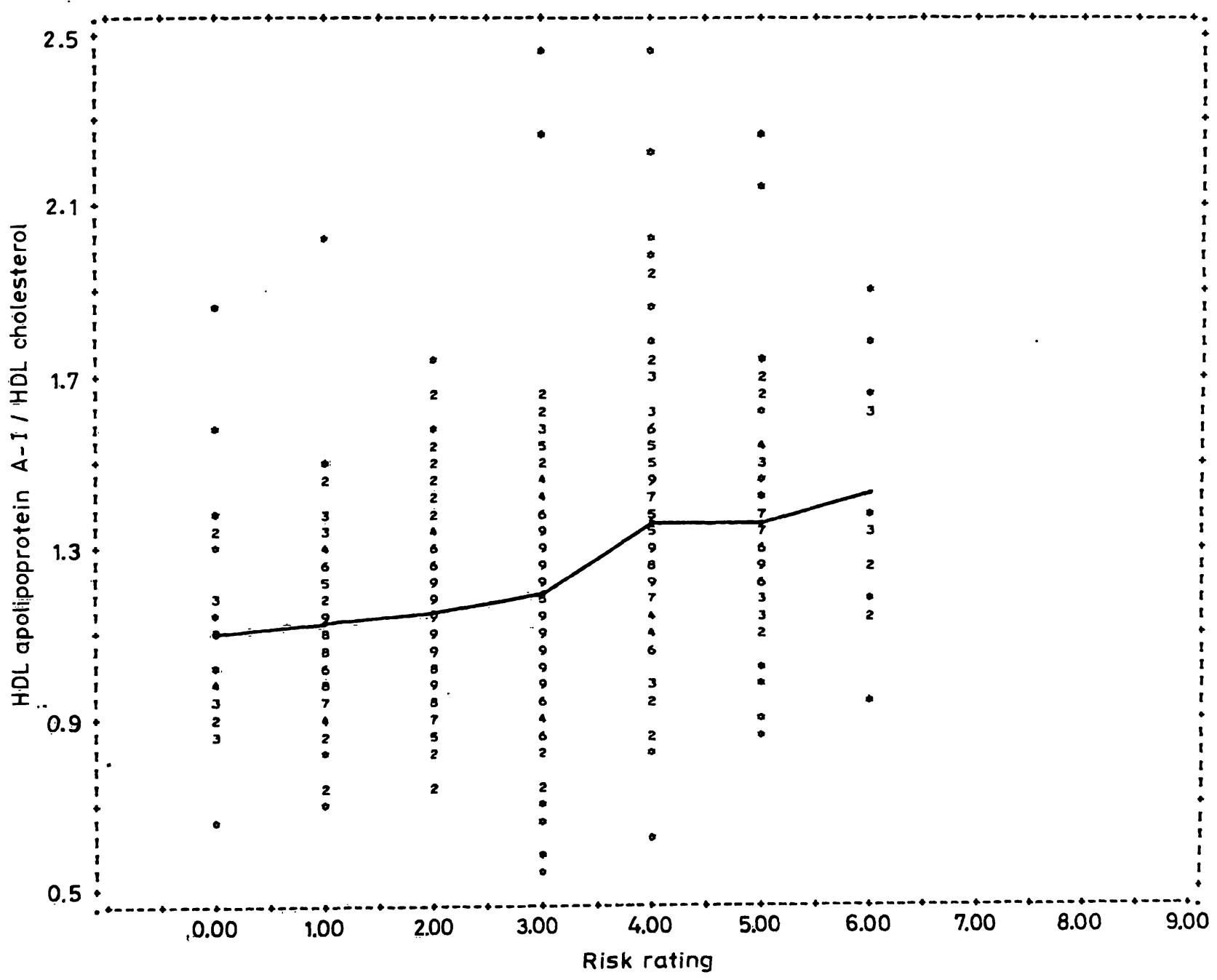

Fig. 4. HDL apolipoprotein A-I/HDL cholesterol ratio in relation to cumulative risk factor rating. A ' 9 ' is printed if 9 or more men have equal values.

$r($ Kendall $)=-0.287(p<0.001)$ 
Tab. 3. Correlation coefficients (Spearman rank correlation) between the ratio, HDL apolipoprotein A-I/HDL apolipoprotein A-II, and cholesterol, triacylglycerol, HDL cholesterol and HDL phosphatidyl choline.

\begin{tabular}{lr}
\hline Cholesterol & -0.061 \\
Triacylglycerol & $-0.124^{*}$ \\
HDL cholesterol & $0.194^{*}$ \\
HDL phosphatidyl choline & $0.174^{*}$ \\
\hline
\end{tabular}

* $\mathrm{p}<0.01$

ratio was negatively correlated with triacylglycerol ( $\mathrm{r}$ : $-0.124, \mathrm{p}<0.001$ ) (fig. 7, tab. 3). In individuals with triacylglycerol $<1.71 \mathrm{mmol} / \mathrm{l}$, the $\mathrm{HDL}$ apolipoprotein A-I/HDL apolipoprotein A-II ratio was found to be higher $(3.51 \pm 0.48)$ than in individuals with triacylglycerol ranging from 1.71 to $2.27 \mathrm{mmol} / 1$ $(3.33 \pm 0.43)$ or hypertriacylglycerolaemic individuals $>2.27 \mathrm{mmol} / 1(3.33 \pm 0.49)$. On the other hand, there were no differences in the HDL apolipoprotein A-I/HDL apolipoprotein A-II ratio between hypertriacylglycerolaemic individuals and individuals with medium triacylglycerol values.

\section{Discussion}

In our present study we report only data on men $\mathbf{4 0}$ years and older, since this group obviously has a higher coronary risk than women or men under 40 . With respect to HDL cholesterol and HDL apolipoprotein A-I, the data obtained from men 40 years and older did not differ significantly from data reported previously for company employees from 25 to 64 years old (12). In addition to our previous study, HDL apolipoprotein A-II values were also measured.

As previously reported (19) and as again shown by the present results, HDL cholesterol has a negative correlation to the individual cumulative coronary risk based on the most frequent risk factors, obesity, hypertension, cigarette smoking, cholesterol and exercise. In comparison with HDL cholesterol, the relation of both ratios, HDL apolipoprotein A-I/HDL cholesterol and HDL apolipoprotein A-II/HDL cholesterol, to the individual cumulative risk did not differ. Furthermore, in individuals with normal or elevated HDL cholesterol values a higher coronary

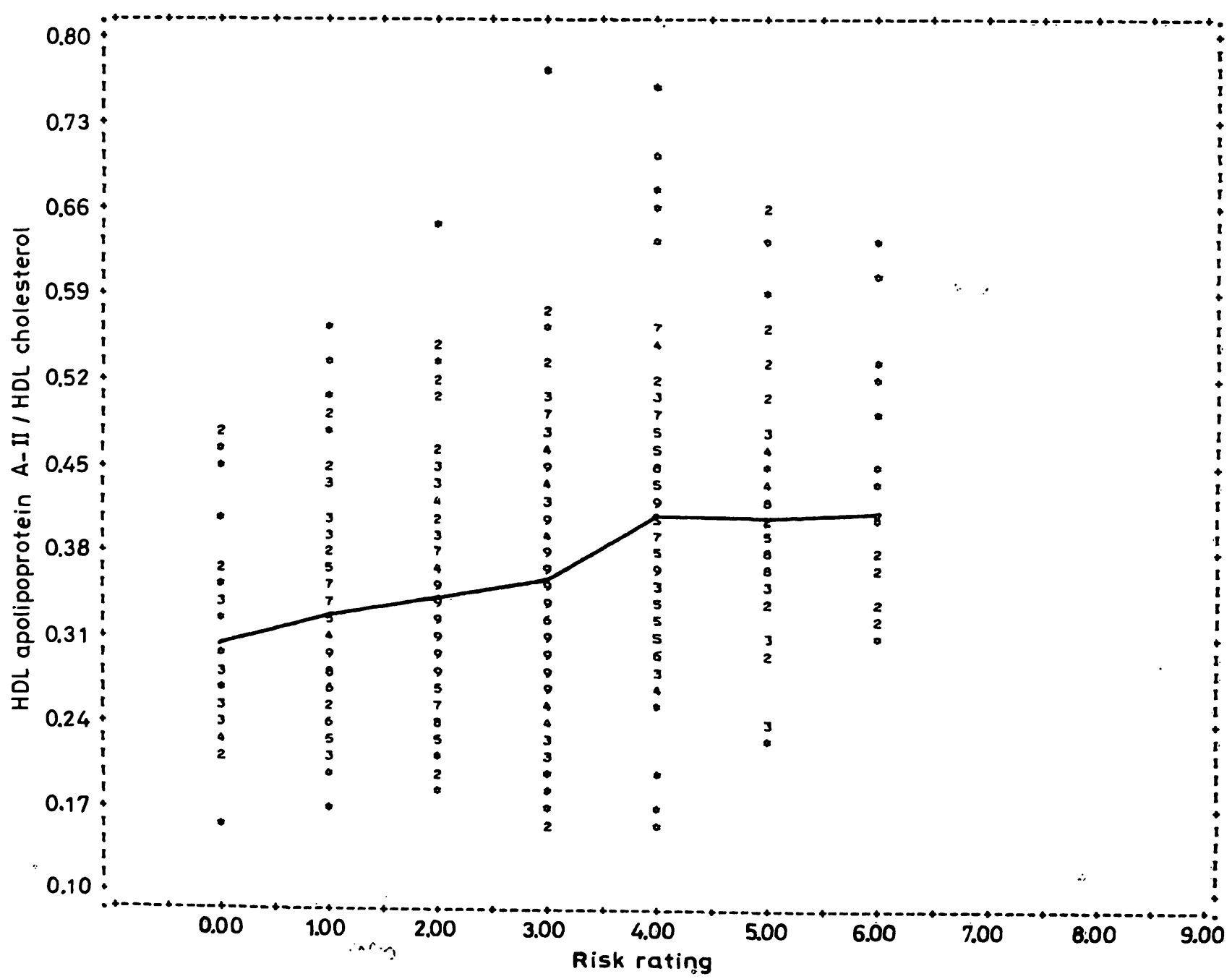
Fig. 5. HDL apolipoprotein A-II/HDL cholesterol ratio in relation to cumulative risk factor rating. A' ' 9 ' is printed if 9 or more
men have equal values.

$r($ Kendall $)=0.300(p<0.001)$ 
risk was associated with a higher ratio of $\mathrm{HDL}$ apolipoprotein A-I/HDL cholesterol and HDL apolipoprotein $\mathrm{A}-\mathrm{II} / \mathrm{HDL}$ cholesterol. The reason for this observation may lie in possible changes in mass and composition of HDL subfractions caused by risk factors and in different associations of HDL subfractions to coronary risk. It is known that changes in plasma $\mathrm{HDL}$ level mainly affect $\mathrm{HDL}_{2}(20)$ and that an inverse correlation exists between HDL and VLDL in plasma (21). Furthermore, it has been shown that a less dense $\mathrm{HDL}_{2}$ subfraction (relative high lipid/apolipoprotein ratio) is epidemiologically associated with reduced coronary heart disease, while a more dense $\mathrm{HDL}_{3}$ subfraction (relatively low lipid/ apolipoprotein ratio) is thought to be unrelated to such disease $(22,23)$. Nevertheless, recent studies have shown that HDL in individuals with hypertriacylglycerolaemia mainly consist of $\mathrm{HDL}_{3}$, which are enriched with apolipoproteins and triglycerides and which are depleted of cholesterol (24). Furthermore, it has been reported that alcohol consumption, which is known to be associated with high HDL cholesterol
(25-27) and frequently with hypertriacylglycerolaemia $(28,29)$, mainly resulted in an enhanced level of $\mathrm{HDL}_{3}$ mass without affecting $\mathrm{HDL}_{2}$ mass (30).

It has been shown that the apolipoprotein A-I/apolipoprotein A-II ratio in $\mathrm{HDL}_{2}$ is higher than that in $\mathrm{HDL}_{3}(31,32)$. Therefore, in individuals with heigh HDL cholesterol levels (which are associated with lower triacylglycerol) and a similarly high apolipoprotein A-I/apolipoprotein A-II ratio, a higher $\mathrm{HDL}_{2} / \mathrm{HDL}_{3}$ ratio may exist in comparison to individuals with lower HDL cholesterol levels (which are associated with higher triacylglycerol) and a similarly low apolipoprotein A-I/apolipoprotein A-II ratio. However, it is of interest to note that the HDL lipoprotein composition in our study did not differ between individuals with moderate hyperlipoproteinaemia and individuals with obviously enhanced lipid levels. Possibly, in hypertriacylglycerolaemics, the HDL apolipoprotein A-I/apolipoprotein A-II ratio may additionally be a reflection of the change in apolipoprotein composition in HDL particles in different density classes.

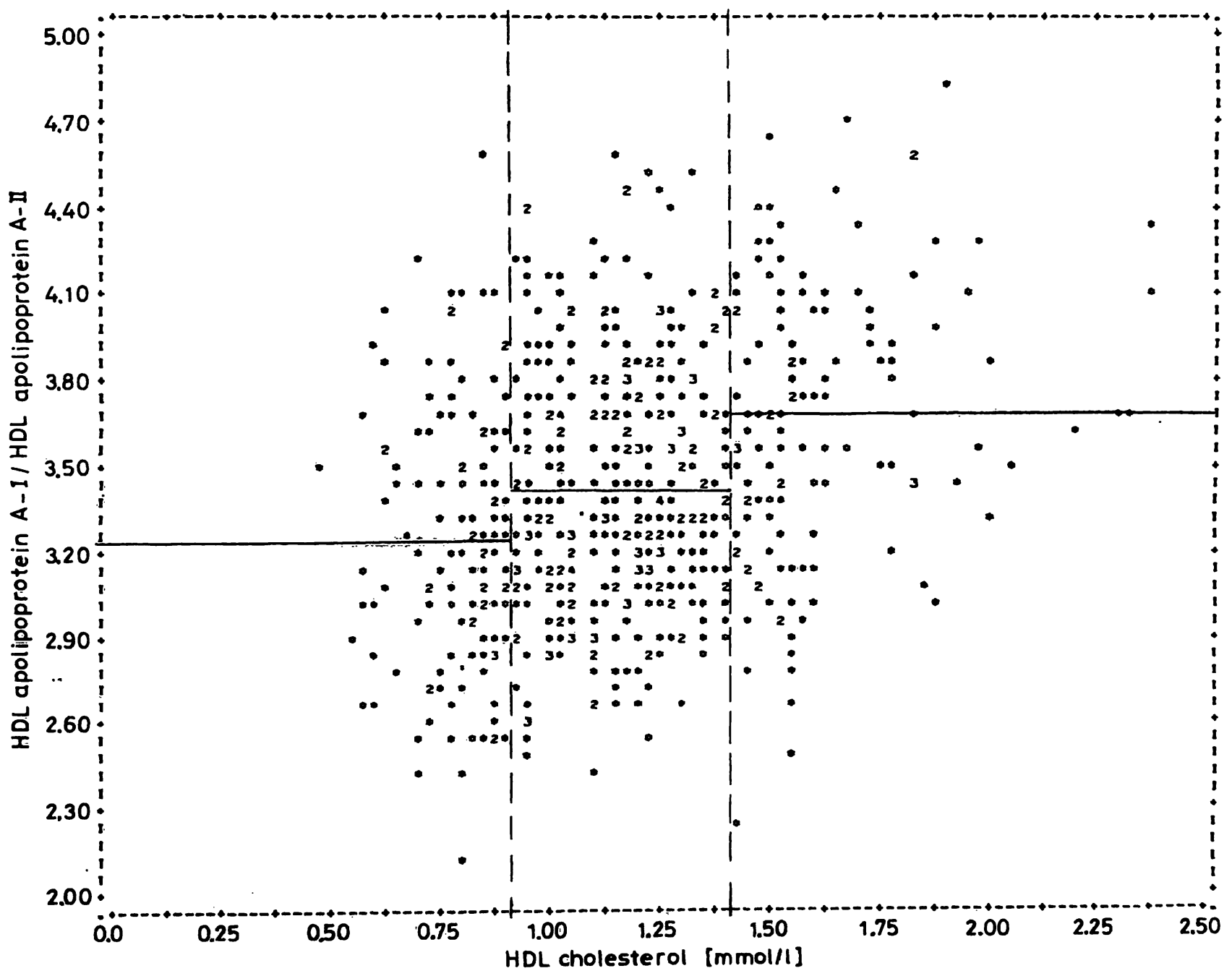

Fig. 6. Bivariate distribution of HDL apolipoprotein A-I/HDL apolipoprotein A-II ratio and HDL cholesterol. $r($ Spearman $)=0.194(p<0.01)$ 


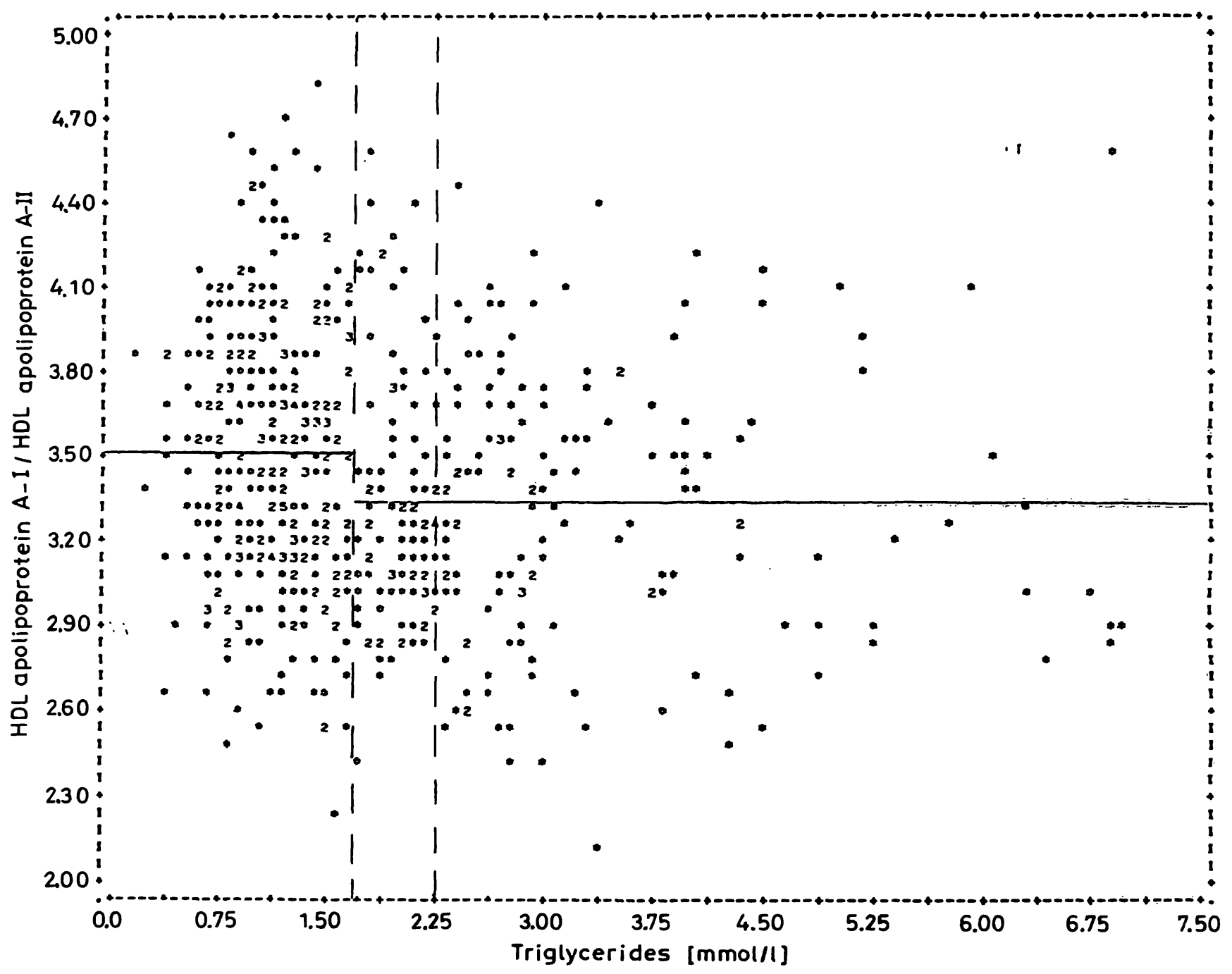

Fig. 7. Bivariate distribution of HDL apolipoprotein A-I/HDL apolipoprotein A-II ratio and triacylglycerol. $\mathrm{r}($ Spearman $)=-0.124(\mathrm{p}<0.01)$

\section{References}

1. Miller, G. J. \& Miller, N. E. (1975) Lancet $I, 16-19$

2. Berg, K., Borresen, A. L. \& Dahlen, G. (1976) Lancet $I$, $499-501$.

3. Gordon, T., Castelli, W. P., Hjortland, M. C., Kannel, W. B. \& Dawber, T. R. (1977) Amer. J. Med. 62, 707-714.

4. Yaari, S., Goldbourt, U., Even-Zohar, S. \& Neufeld, H. N. (1981) Lancet $I, 1011-1015$.

5. Barboriak, J. J., Anderson, A. J., Rimm, A. A. \& King, J. F. (1979) Metabolism 28, 735-138.

6. Kladetzky, R. G., Assmann, G., Walgenbach, S., Tauchert, P. \& Helb, H.-D. (1980) Artery 7, 191-205.

7. Ishikawa, T., Fidge, N., Thelle, D. S., Forde, O. H. \& Miller, N. E. (1978) Eur. J. Clin. Invest. 8, 179-182.

8. Avogaro, P., Bittolo Bon, G., Cazzalato, G. \& Rorai, E. (1980) Atherosclerosis 37, 69-76.

9. Maciejko, J. J., Holmes, D. R., Kottke, B. A., Zinsmeister, A. R., Dinh, D. M. \& Mao, S. J. T. (1983) New Engl. J. Med. 309, 385-389.

10. Albers, J. J., Cheung, M. C., Hazzard, W. R. (1978) Metabolism 27, 479-485.

11. Riesen, W. F., Mordasini, R., Salzman, C., Thaler, A. \& Gurtner, H. P. (1980) Atherosclerosis 37, 157-162.

12. Assmann, G., Funke, H. \& Schriewer, H. (1982) J. Clin. Chem. Clin. Biochem. 20, 287-289.
13. Assmann, G., Oberwittler, W., Schulte, H., Schriewer, H., Funke, H., Epping, P. H. \& Hauss, W. H. (1980) Internist $21,446-459$.

14. Assmann, G., Schriewer, H., Schmitz, G. \& Hãgele, E. $O$. (1983) Clin. Chem. 29, 2026-2030.

15. Schriewer, H., Jung, G., Emke, F. \& Assmann, G. (1983) J. Clin. Chem. Clin. Biochem. 21, 611-614.

16. Assmann, G., Schriewer, H. \& Funke, H. (1981) J. Clin. Chem. Clin. Biochem. 19, 273-278.

17. Schriewer, H., Emke, F. \& Assmann, G. (1985) J. Clin. Chem. Clin. Biochem. 23, 355-359.

18. Friedewald, W. T., Levy, R. I. \& Fredrickson, D. S. (1972) Clin. Chem. 18, 499-509.

19. Williams, P., Robinson, D. \& Bailey, A. (1979) Lancet $I$, $72-75$.

20. Anderson, D. W., Nichols, A. V., Pau, S. S. \& Lindgren, F. T. (1978) Atherosclerosis 29, 161-179.

21. Nichols, A. V. (1967) Human serum lipoproteins and their interrelationships. In: Advances in Biological and Medical Physics (Lawrence, J. H., Gofman, J. W. \& Hayes, T. L. eds.) pp. 110-158, Academic Press, New York.

22. Miller, N. E., Hammett, F., Saltissi, S., Rao, S., van Zeller, H., Coltard, J. \& Lewis, B." (1981) Br. Med. J. 282, $1741-1744$. 
23. Ballantyne, F. C., Clark, R. S., Simpson, H. S. \& Ballantyne, D. (1982) Metabolism 31, 433-437.

24. Eisenberg, S, Gavish, D., Oschry, Y., Fainaru, M. \& Deckelbaum, R. J. (1982) J. Clin. Invest. 74, 470-482.

25. Belfrage, P., Berg, B., Hägerstrand, J., Nilsson-Ehle, P., Tornqvist, H. \& Wiebe, T. (1977) Eur. J. Clin. Invest. 7, 127-131.

26. Hulley, S. B. \& Gordon, S. (1981) Circulation 64, Suppl. 3: III, 57-63.

27. Fraser, G. E., Anderson, J. T., Foster, N., Goldberg, R., Jacobs, D. \& Blackburn, H. (1983) Atherosclerosis 46, 275-286.
28. Barona, E. \& Lieber, C. S. (1979) J. Lipid. Res. 20, 289-315.

29. Sabesin, S. M. (1981) Circulation 64, suppl. III, $72-84$.

30. Haskell, W. L., Camargo, C., Williams, P. T., Vranizan, K. M., Krauss, R. M., Lindgren, F. T. \& Wod, P. D. (1984) New Engl. J. Med. 310, 805-810.

31. Kostner, G. M., Patsch, J. R., Sailer, S., Braunsteiner, H. \& Holasek, H. (1974) Eur. J. Biochem. 45, 611-621.

32. Cheung, M. C. \& Albers, J. J. (1977) J. Clin. Invest. 60 , $43-50$.
Professor Dr. H. Schriewer Institut für Klinische Chemie und Laboratoriumsmedizin Medizinische Einrichtungen der Westf. Wilhelms-Universität Albert-Schweitzer-Straße 33 D-4400 Münster 


\section{DELTA EF 500 FILTERPHOTOMETER}

Ein DELTA EF 500 Präzisionsphotometer aus dem "economic program" von DELTA ELEKTRA ist die ideale Hilfe für Messungen im Routinelaboratorium.

Dafür sorgen funktioneller Aufbau, moderne Elektronik, Digitalanzeige von Absorbance und vier Konzentrationen, automatische Nullpunktkompensation, genaue Linearität und Reproduzierbarkeit.

Für größere Serien verfügt das

DELTA EF 500 über eine Absaugküvette und eingebaute Pumpe sowie analoges Ausgangssignal.

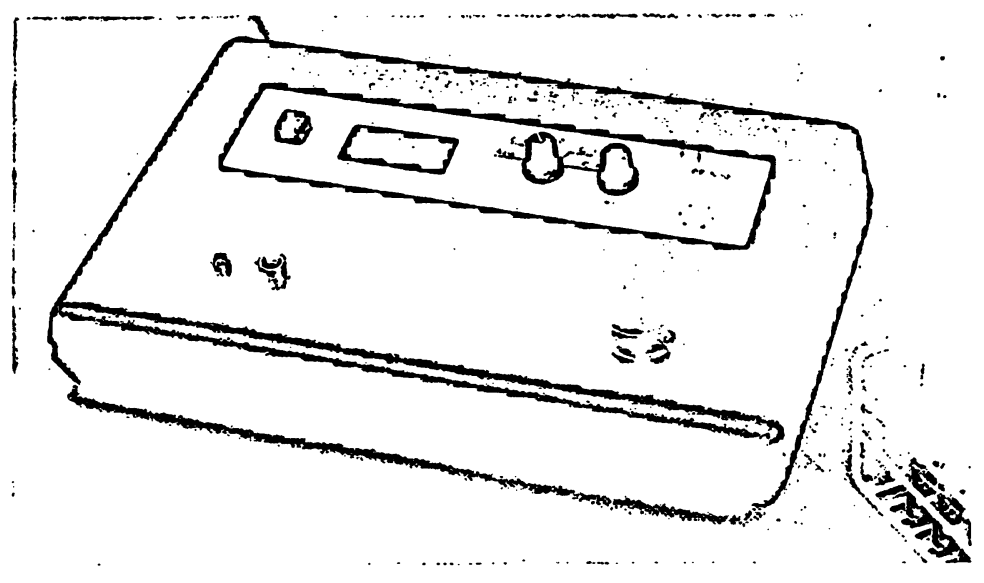

DELTA ELEKTRA

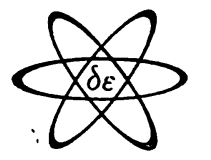

Information verschaffen der Hersteller und Ihr Fachhändler. Verlangen Sie eine Vorführung, denn das DELTA EF 500 bedeutet einen Ihr Laborpartner aus Holland Durchbruch im Produkt/Preis Verhältnis.

DELTA ELEKTRA B. V. - Rijksweg 29 - NL - 7975 RT Uffelte

Trace Element

Analytical Chemistry in Medicine and Biology Volume 3

Proceedings of the Third International

Workshop - Neuherberg, Federal Republic of Germany, April 1984

Editors P. Brätter, P. Schramel

1984. $17 \mathrm{~cm} \times 24 \mathrm{~cm}$. XVI, 763 pages. Numerous illustrations.

Hardcover. DM 240,-; approx. US \$80.00 ISBN 3110098210

The proceedings contained in this volume are specifically concerned with new developments in the field of the essential trace elements selenium, zinc and manganese as well as with current problems in analysis, nutrition and medicine. The actual state of knowledge about other recently recognized essential trace elements also played a dominant role.

Price is subject to change without notice

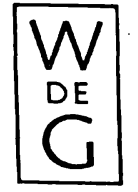
Walter de Gruyter · Berlin · New York 